\title{
THE EFFECT OF REVENUE AND MARKET SEGMENTATION LEVEL TOWARDS VENTURE CAPITAL INVESTMENT IN MOBILE APPLICATION BUSINESS
}

\author{
Dennis Adrian ${ }^{1}$; Riswan Efendi Tarigan ${ }^{2}$ \\ ${ }^{1}$ President Director, JakMaster IT Solutions \& Printworks \\ Jl Cilincing Raya, Ruko Cilincing Plaza Blok A1 No. 1, Jakarta, Indonesia, mr.dennisadrian@yahoo.com \\ ${ }^{2}$ Master of Information System, Faculty of Information Technology, Bina Nusantara University \\ Jl Kebon Jeruk Raya No. 27, Jakarta 11530, Indonesia, re.tarigan@gmail.com
}

\begin{abstract}
The development of mobile applications has mushroomed in local and foreign industries. This provides a tremendous opportunity for developers. For technopreneur developer, the capital to run the business is one of the biggest problems despite the fact that they may have great competence in the field. The fact that the business has big potential market in Indonesia has invited investors from local and overseas to invest as venture capital. However, due to the lack of knowledge on building collaboration with the investors and on understanding the market and investor needs in a long term, the developer finds difficulties to grow its business and to compete with bigger competitors. The research intends to seek the influence in selecting the level of revenue and market segmentation to support the investment decisions in the business of mobile applications, so that the mobile application developer is able to monetize their business to attract investors to invest in the venture capital.
\end{abstract}

Keywords: Investment Decisions, Venture Capital, Mobile Applications, Revenue Levels, Market Segmentation

\section{INTRODUCTION}

The development of mobile applications has mushroomed in local and foreign industry. This provides a tremendous opportunity for developers. For technopreneur developer, the capital to run their business creates a problem that is often experienced even though they have great competence in the business. Whereas, the market share in Indonesia is very large and it invites investors from both local and overseas to invest as venture capital. However, due to lack of knowledge about how to work together with the investors and how to give the desired value and a long-term sustainable market to the investor, it makes the developer difficult to grow its business and to compete with bigger competitors.

With growing investment, financial characteristics have a major role for a person in making a decision to invest. Finance decision making for investment will be influenced by obtaining information and investor's knowledge about investment. All this time, an investor's decision in investment is seen from two sides, which are (1) How far the decision can maximize wealth (economic); (2) Decision in investment is based on psychology aspect of the investor (behavioral motivation)

Usually an investor will do a research before making a decision, like studying company's financial statement, performance, track record (portfolio), economy condition, the risk, and finance and economy reviews that are published in media. This study was conducted to provide additional wealth on investments made. According to the utility theory, which is developed by reff [1], (1) investor is very rational; (2) agree with complex decision; (3) do not like risk and; (4) maximize wealth. Over the years, other theories have emerged that may affect an investor's decision to invest, based on the aspects of psychology (behavioral motivation). Other than that, according to empirical study about investor characteristic which is conducted by reff [2] testing about how demography variable can affect the process of deciding the composition of portfolio investment.

Other factor that can affect decision making of investor's investment is behavioral motivation which can be seen from demography variable, like gender, age and education. Reff [3] sets that age, gender, earning and education affect investor's choice for profit, dividend and all profits which are wanted. Moreover (Warren and friends, 1990) [3] say that a investor's choice is more based on lifestyle and demography characteristic.

Many investors in making decision to invest only see and consider accounting information factor, so the goal of investment can be achieved. However, the other factors aren't considered. That factors are often called as traditional analysis tools and investor often feels that it is enough by seeing the two factors to make decision in investment. In addition, many 
investors do not know that there is other factors which can be used as consideration before doing an investment.

\section{GOAL}

The goal of this study is to find out about effect of restoration revenue towards decision to invest in venture capital in mobile application business. To find out about effect of choosing market segmentation which is chosen by developer towards decision to invest in venture capital in mobile application business. And to find out the most dominant and affecting factor that affects the decision making in mobile application business investment. The result of this study will give a recommendation to developers to monetize mobile application business that they run.

\section{LITERARY REVIEW}

This part is literary review about supporting theories which is used in analysis and research discussion.

\section{Investment Theory}

There are several investment theories according to experts. According to reff [4], the activity which is held with utilizing cash in the present time. Investment's meaning according to reff [5] is an asset which is used by company for growing wealth thorough the result of investment distribution (like interest revenue, royalty, devidend, rent revenue and others), for appreciating investment value, or other benefits for company to invest, like benefit which is got from trading. According to reff [6] investment can be interpreted as capital implantation in an activity which has relatively long period of time in many business sectors. Capital implantation which is implanted in small meaning is a certain project that is physical or non-physical, like project about building a factory, road, bridge, a building and research project, and development.

Sourced from the other theory about investment, according to reff [7], investment is an effort to implant rare production factors in certain project. Both are completely new or expanding project or existing factory to get finance benefit and or nonfinance benefit which are feasible later. According to reff [8], he states that "investment is attribution of sources in long term to yield revenue in future time.

\section{Venture Capital}

Venture capital is long term investment in the form of giving capital that consists of risk where capital provider hopes capital gain [9]. According to reff [10], venture capital is fund that is invested into a company or an individual that has high risk. Moreover, according to reff [11], venture capital is financing business that enables forming and developing new business in technology field and or technology. Quoted from reff [12], "venture capital company is a financing enterprise in form of capital inclusion into a company which receives financing help for certain time".

There can be concluded that venture capital is an investment in form of financing, like capital inclusion into a private company as an investee company for certain time. In general, this investment is done in form of capital handover in cash which is exchange with some shares in an investee company. This venture capital investment often has high risk, but gives a great profit as well. Venture capitalist is an investor who invests in a venture capital company. This venture fund manages investment fund from third party (investor) with the main goal to do an investment in a company that has high risk so that it won't fulfill the standard requirement as open company or to get loan capital from bank. This venture capital investment also includes giving managerial and technical help. Most of this venture fund is from investor group who has established finance, bank investment, and other finance institution which does fund collecting or partnership for the goal of that investment. Capital inclusion which is done by venture capital mostly done towards companies that is recently established, so that it doesn't have any operational history which can be used as note to get a loan. As an entrepreneurship, venture capital owner often has right as way determinant in company policy according to share amount that he has.

\section{Revenue}

Revenue is the result of handover good or service that has been produced in company operation. Revenue is a key element in determining the level of benefits that can be seen as the company's achievements in operating the company in a given period. According to reff [13] in his book "accounting theory" states that revenue is inrush or increasing value of asset of an entity or settlement of its loan (or combination of both) during a certain period from the delivery or manufacture of good. Provision of service or implementation of other activities which are the main activity are ongoing of that entity.

From several understanding about revenue above, it can be concluded that revenue is inrush of gross or the increasing value of asset and decreasing of liability from the normal activity in the company during a certain period which is stated in monetary unit.

\section{Sources of Revenue}

According to reff [14], revenue which is gained by company based on the sources is divided into two groups: (1) Operating revenue. It is a revenue that is received by company that is related directly to the main business of that company. (2) Non operating revenue. It is a revenue that is received by company 
that does not have any direct relation with the company's main business.

\section{Definition of Market Segmentation}

Market segmentation is an activity of splitting market which is heterogeneous into market units which are homogeneous [15]. There is also an opinion of reff [15] that formulates market segmentation as an act of splitting market into certain market segmentations as into sales target that will be achieved using marketing mix. While, definition which is given by reff [16] says that market segmentation is a process of splitting market into potential customer segmentations with similar characteristic which shows there is similarity in customer's behavior.

\section{Market Segmentation Variables}

Relating with this, reff [17] classifies types of segmentation variable as follow: (1) Geography segmentation. (2) Demography segmentation (3) Psychography segmentation. (4) Behavior segmentation

\section{Previous Research} table 1.

Synthesis of previous research can be seen on

Table 1: Research tools

\begin{tabular}{|c|c|c|c|}
\hline Researchers & Dimension & $\begin{array}{l}\text { Analysis } \\
\text { method }\end{array}$ & Result \\
\hline $\begin{array}{l}\text { Dimas Prasetyo, } \\
\text { Zahroh Z.A } \\
\text { dan Devi Farah } \\
\text { Azizah (2011) } \\
{[18]}\end{array}$ & $\begin{array}{l}\text { The effect of } \\
\text { investment } \\
\text { decision } \\
\text { and funding } \\
\text { decision towards } \\
\text { company value } \\
\text { (study in a } \\
\text { property and real } \\
\text { estate company } \\
\text { registered in } \\
\text { BEI 2009-2011 } \\
\text { period) }\end{array}$ & $\begin{array}{l}\text { Quantitative } \\
\text { (Explanatory } \\
\text { Research) }\end{array}$ & $\begin{array}{l}\text { Investment } \\
\text { decision and } \\
\text { funding decision } \\
\text { take significant } \\
\text { effect towards } \\
\text { company value }\end{array}$ \\
\hline $\begin{array}{l}\text { Lihan Rini Puspo } \\
\text { Wijaya, Bandi } \\
\text { dan Anas Wibawa } \\
\text { (2010) [19] }\end{array}$ & $\begin{array}{l}\text { The effect of } \\
\text { investment } \\
\text { decision } \\
\text { and funding } \\
\text { decision and } \\
\text { policy towards } \\
\text { company value }\end{array}$ & $\begin{array}{l}\text { Quantitative } \\
\text { (Regresion } \\
\text { Model) }\end{array}$ & $\begin{array}{l}\text { Investment } \\
\text { decision and } \\
\text { funding decision } \\
\text { and policy take } \\
\text { positive effect } \\
\text { towards company } \\
\text { value }\end{array}$ \\
\hline $\begin{array}{l}\text { Putu Terestiani } \\
\text { Dadri (2011) [20] }\end{array}$ & $\begin{array}{l}\text { The effect of } \\
\text { investment } \\
\text { opportunity } \\
\text { set and capital } \\
\text { structure } \\
\text { towards } \\
\text { share return } \\
\text { in pharmacy } \\
\text { company in } \\
\text { Indonesia stock } \\
\text { exchange }\end{array}$ & $\begin{array}{l}\text { Quantitative } \\
\text { (Regression } \\
\text { Model) }\end{array}$ & $\begin{array}{l}\text { Investment } \\
\text { opportunity } \\
\text { set and capital } \\
\text { structure has } \\
\text { significant effect } \\
\text { to return share } \\
\text { in pharmacy } \\
\text { company in } \\
\text { Indonesia stock } \\
\text { exchange }\end{array}$ \\
\hline
\end{tabular}

Based on the synthesis of several previous researches (table 1), it can be seen that investment decision and funding have significant effect towards company value. Thus, this study is the continuation of previous researches to find out the effect of reversion of revenue level towards decision in investment. The effect of choosing market segmentation to investment decision and the effect of the most dominant factors in deciding to invest especially in mobile application business.

\section{METHOD}

This part explains about the research methodology which is taken. It includes the research model, population and sample that are used, collecting data methodology, and hypothesis, also analysis tool that is used.

\section{Research Model}

The concept of this research refers to revenue study, market segmentation and other factors. Those factorsare Revenue (RV), Psychography (PG), Demography (DG), Geography (GG), Behavior (BV) and Supporting Factors (SF). Venture capital investment will be related to the dimension of revenue level and market segmentation (picture 1).

\section{Population and Sample}

Population and sample are obtained from investors that are listed in Jakarta Stock Exchange or ever listed in Jakarta Stock Exchange and ever making investments in Jakarta. The research sample is investors that are listed in Jakarta Stock Exchange or ever listed in Jakarta Stock Exchange or ever making investments in mobile application business. Collecting data is done in four weeks.

\section{Collecting Data Methodology}

Collecting data methodology which is used in this research is: (1) Interview. (2) Questionnaire.

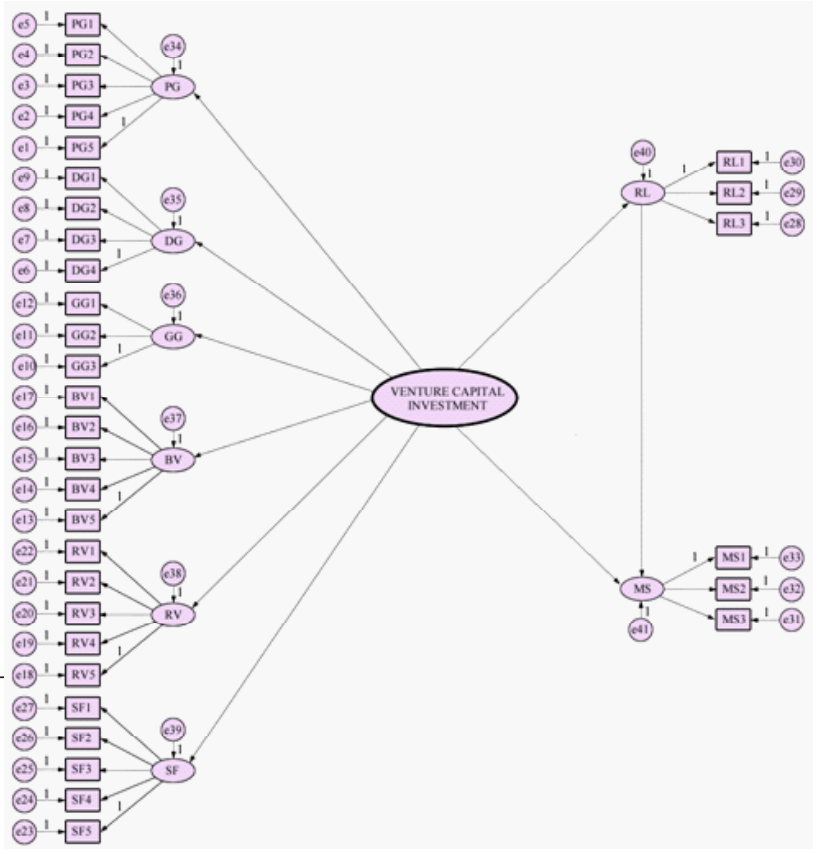

Fig. 1: Research Model 


\section{Hypothesis}

To explain the effect of revenue and market segmentation towards venture capital investment decision in mobile application business, then the hypothesis can be made like below:

H1: the higher revenue reversion, then the higher the venture capital investment decision in mobile application business.

$\mathrm{H} 2$ : demography aspect in market segmentation gives significant effect to venture capital investment decision in mobile application business.

H3: factor in revenue reversion is the most dominant that affects venture capital investment decision in mobile application business.

\section{Analysis Tool which is Used}

Analysis tool which is used in this research is: (1) Likert scale method. It is a common scale psychometric which is used in questionnaire, and is scale which is the most used in research in form of survey. When responding the question in Likert scale, respondents determine their level of agreement towards a statement by choosing one of the available choices. The question is prepared in five scale choices with the format like these; Strongly disagree, Disagree, Doubtful, Agree, Strongly agree. (2) SEM analysis ( Structure Equation Model)

By using SEM analysis, structural sample examination and measurement enable researcher to test measurement error as an inseparable part of Structural Equation modeling and to do factor analysis as well with hypothesis testing. In SEM analysis, there is exogenous variable and endogenous variable. Exogenous variable is often as independent variable (X var in regression) which is not affected by other variable in a model. While endogenous variable is a variable that is affected by other variables in a model ( $\mathrm{Y}$ var in regression)

\section{RESULTS AND DISCUSSION}

Result and conclusion elaborates the result of the research which is done. Start with introduction, respondent's profile, validity and reliability, result of SEM analysis and explanation of hypothesis.

\section{Introduction}

This research will use SEM method in processing the data. Based on the research model, processing data passes several steps, including processing data 1 st order for venture capital investment decision variables, then continuing with processing data 2 nd order or processing all variable exogenous and endogenous data, after that equation of structural for all research models are done. However, before entering steps above, there will be validity and reliability test to research indicators.

\section{Respondent Profile}

Respondents who are asked to fill the questionnaire are the investors who are investing in several mobile application companies in Jakarta. This research is done on January 2014 till February 2014. After the data has been collected, it turns out the returned questionnaires is 69 or $23 \%$ from all questionnaires. Then, the data is processed using SPSS to analyze frequency and cross tab, and here is the result:

Table 2: Frequency gender type of the respondents

\begin{tabular}{lcccc}
\hline & Freq. & Percent & Valid & $\begin{array}{c}\text { Cumulative } \\
\text { Percent }\end{array}$ \\
\hline Woman & 10 & 14.5 & 14.5 & 14.5 \\
Man & 59 & 85.5 & 85.5 & 100.0 \\
\hline Total & 69 & 100.0 & 100.0 & \\
\hline \multicolumn{5}{l}{ Source: data processed }
\end{tabular}

Based on analysis using descriptive frequency method, from 69 respondents for gender frequency is obtained that respondent with male gender is more than female respondent. This can happen because there is not too many women who want to or are brave to invest in capital market, since women are more afraid with the risk than men. Khan in reff [21] and in reff [22] state that women have emotionality warmth, reserved and sensitivity more than men. While for emotional level, women is more emotional so their emotion maturity level is lower than men who are more rational and use logic so their emotion maturity level is higher. Shields in reff [23] and in reff [22] goal or investment's benefit between men and women is also different, men aim for getting living while women for fulfilling their emotion to give attention to family.

Table 3: Frequency age of respondents

\begin{tabular}{lcccc}
\hline & Freq. & Percent & $\begin{array}{c}\text { Valid } \\
\text { Percent }\end{array}$ & $\begin{array}{c}\text { Cumulative } \\
\text { Percent }\end{array}$ \\
\hline $20-24$ & 17 & 24.6 & 24.6 & 24.6 \\
$25-29$ & 21 & 30.4 & 30.4 & 55.1 \\
$30-34$ & 12 & 17.4 & 17.4 & 72.5 \\
$35-39$ & 9 & 13.0 & 13.0 & 85.5 \\
$40-44$ & 3 & 4.3 & 4.3 & 89.9 \\
$45-49$ & 5 & 7.2 & 7.2 & 97.1 \\
$50-54$ & 2 & 2.9 & 2.9 & 100.0 \\
\hline Total & 69 & 100.0 & 100.0 & \\
\hline & Source: data processed
\end{tabular}

To analyze frequency based on age, it is seen in Table 3. Which respondents' average age is 25-29 years, which at this age, investor is in productive age and phase of developing career and family affair so all abilities are used to work and get money as much as they can for their retirement day. 
Table 4: Frequency education of respondents

\begin{tabular}{lcccc}
\hline & Freq. & Percent & $\begin{array}{c}\text { Valid } \\
\text { Percent }\end{array}$ & $\begin{array}{c}\text { Cumulative } \\
\text { Percent }\end{array}$ \\
\hline SMA & 2 & 2.9 & 2.9 & 2.9 \\
S1 & 63 & 91.3 & 91.3 & 94.2 \\
S2 & 4 & 5.8 & 5.8 & 100.0 \\
\hline Total & 69 & 100.0 & 100.0 & \\
\hline \multicolumn{5}{l}{ Source: data processed }
\end{tabular}

Based on the analysis of frequency of respondents' education, it is dominated by respondents with bachelor degree which is quite high in education level. At this education level, this can be classified in $>25$ years, which is investors who have already had better knowledge and thinking, where the analysis and the decision making are good.

Table 5: Frequency time of investment of respondents

\begin{tabular}{lcccc}
\hline & Freq. & Percent & $\begin{array}{c}\text { Valid } \\
\text { Percent }\end{array}$ & $\begin{array}{c}\text { Cumulative } \\
\text { Percent }\end{array}$ \\
\hline < I year & 1 & 1.4 & 1.4 & 1.4 \\
1-3 year & 46 & 66.7 & 66.7 & 68.1 \\
4-6 year & 13 & 18.8 & 18.8 & 87.0 \\
$>$ 6 year & 9 & 13.0 & 13.0 & 100.0 \\
\hline Total & 69 & 100.0 & 100.0 & \\
\hline
\end{tabular}

Source: data processed

The most frequency of how long respondent's investment is in 1-3 year, where respondent is still in first stage of introduction and developing investment. This is because in recent 5 year, capital market in Indonesia is interested by investor from year to year.

\section{Validity and Reliability}

To fulfill criteria of a research, so it can be called as a scientific research, accurate measurement is needed. There are two main requirements that must be fulfilled by tools to get accurate measurement, which are Validity and Reliability.

Validity means tool that is used in measurement to measure what it is supposed to measure. Validity test is meant to test accuracy in items in questionnaire, whether the available items can show and explain variable that is researched. So validity is how far the tool can measure thing or subject that is wanted to be measured.

Validity is cultivated with logic thinking, to ask experts' opinions, using group's characteristic which is already known, independent criteria. Item that is used in this research will be tested next about the reliability.

Reliability means having trusted characteristic, which is when the measurement tool is used several times by the same researchers and by others, it will be still the same. So reliability is how far the consistency of measurement tool can give the same result in measuring the same subject.

Reliability test is used to measure a questionnaire which is indicator or variable or construct. A questionnaire is said to be reliable if someone's answer to the statement is consistent and stable from time to time. Measurement with one shot or one time measurement is used in this research. According to reff [24], a construct or variable is said to be reliable, if it gives Cronbach alpha $>0.60$ value [24]

Validity test is done by using factor analysis which is factor loading to make sure that every question is clarified with the determined variable. Criteria to the significance of factor loading, as follow: 0.3 is classified as significant, 0.4 is classified as more significant, and .0 .5 is classified as the most significant [25].

\section{Result of SEM Analysis}

The result of data analysis shows all indicators which are used form a research model, in this analysis process confirmatory has fulfilled determined goodness of fit criteria. Probability value in this research shows value above the significance border which is 0.783 or above 0.005 and other congruence indexes like GFI (0.851), AGFI (0.923), TLI (0.949), CFI (0.952), RMSEA (0.025). This result gives enough confirmation to explain that revenue and market segmentation variable level can mirror latent analyzed variable.

Table 6: Frequency time of investment of respondents

\begin{tabular}{lccc}
\hline \multicolumn{1}{c}{ Model } & $\begin{array}{c}\text { Limit } \\
\text { Eligibility }\end{array}$ & $\begin{array}{c}\text { Model } \\
\text { result }\end{array}$ & Information \\
\hline Chi-square (CMIN) & & 1019.231 & \\
Degree of freedom & & 912 & \\
Probability level $(p)$ & $>=0.05$ & 0.000 & Good \\
CMIN/DF & $<=2.00$ & 1.179 & Good \\
GFI & $>=0.90$ & 0.851 & Enough \\
AGFI & $>=0.90$ & 0.923 & Good \\
TLI & $>=0.95$ & 0.949 & Good \\
CFI & $>=0.95$ & 0.952 & Good \\
RSMEA & $<=0.08$ & 0.025 & Good \\
\hline
\end{tabular}

Table 6 shows all default model values from seven measurement tools (CMIN, Probability, CMIN/DF, TLI, CFI, and RMSEA). It shows quite high number, although there is some below from provision but it is still normal when it is seen from many respondents and indicators. Numbers above indicate the available model fits the available data. Thus model modification is not any longer needed. 
Output structural estimates parameter can be used to test exogenous and endogenous construct relation in model structural. The result of testing estimates parameter can be seen on regression weight part in output estimates. While for close relation between variables can be seen in standardized regression weight in output estimates. Based on output AMOS result, it can be obtained that each regression weight and standardized regression weight can be seen on Table 7 .

\section{Analysis explanation}

Table 7: Hypothesis explanation

\begin{tabular}{lcccc}
\hline & Estimate & $\begin{array}{c}\text { P } \\
\text { value }\end{array}$ & Hypothesis & Result \\
\hline $\begin{array}{l}\text { Investment } \\
\text { decision } \leftarrow \\
\text { Revenue level }\end{array}$ & 0.440 & 0.002 & $\mathrm{H} 1$ & accepted \\
$\begin{array}{l}\text { Investment } \\
\text { decision } \\
\leftarrow \text { Market }\end{array}$ & 0.498 & 0.005 & $\mathrm{H} 2$ & Accepted \\
$\begin{array}{l}\text { segmentation } \\
\text { Investment } \\
\text { decision } \leftarrow\end{array}$ & 0.373 & 0.000 & $\mathrm{H} 3$ & Accepted \\
Revenue & & & & \\
\hline
\end{tabular}

\section{CONCLUSION}

Referring to the result of research above, it delivers that $\mathrm{H} 1$ is accepted, so this research states that there is significant relation between revenue level and venture capital investment.

While for market segmentation variable, it can be concluded that based on demography factor, investors who are 25-29 and 50-54, consider almost all factors, while for below 25 and above 29 until 50 doesn't consider factors too much. However seeing from the gender, female investors are still afraid so they are careful in making decision because all factors are so being considered in investment decision. Education level also affects someone's investment decision, with education level that is already classified as high doesn't make investors confident to decide which factors are more important, investors with bachelor degrees also considers all factors which are related with their investment activity. In other word, the result of research is also parallel with second hypothesis (H2 is accepted).

Beside three aspects above, how long investors are in investment also affects in deciding which factors that should be considered. Investors who are classified as new is 1-3 year still notice and consider all factors before making decision, while investors who have invested for long time, have started decreasing factors that must be considered in investment decision.
Suggestion for the next research is:

a. The research result can be adopted and applied in most mobile application business that includes investors in investment

b. This can add other factors, for example how long the time is for return investment to be tested as thing that affects investors' decision in investment since this is included in investors' consideration.

\section{REFERENCES}

[1] Von Neumann, J. dan Morgenstern, O. Theory of Games and Economic Behaviour. Princeton University Press, 1994.

[2] Blume, Marshall. Portfolio Theory: A Step Toward Its Practical Application. Journal of Business. XLIII (April, 1970), 152-173.

[3] Lewellen, Wilbur, Lease, R. C., \& Schlarbaum. Zattern of Investment Strategy and Behavior among Individual Investors. The Journal of Business, 1977.

[4] Van Horne, James C. Financial Management and Policy, Fifth edition, 1981.

[5] Henry Simamora. Akuntansi Basis Pengambilan Keputusan Bisnis, Jakarta: Salemba Empat., 2000.

[6] Kasmir dan Jakfar. Studi Kelayakan Bisnis. Edisi Revisi. Kencana Prenada Media Grup. Jakarta, 2012.

[7] Sutojo, S. Studi Kelayakan Proyek: Teori dan Praktek. PT. Pustaka Binaman Pressindo. Jakarta Pusat, 1993.

[8] Mulyadi. Sistem Akuntansi, Edisi Ketiga, Cetakan Ketiga, Penerbit Salemba Empat, Jakarta, 2001.

[9] Tony Lorenz. Venture Capital To Day, 1989.

[10] Richardson, Clinton. "The Venture Magazine: Complete Guide to Venture Capital", American Library, NY, 1987.

[11] White, Robert. What is venture Capital and Leverage buy Out Fund investing. First Nasdaq institute Seminar, February, 1990.

[12] Surat Keputusan Presiden Nomor 61 Tahun 1988 Tanggal 20 Desember 1988 Tentang Lembaga Pembiayaan.

[13] Belkaoui, Ahmed Riahi. Teori Akuntansi, Diterjemahkan oleh Marwata dkk. Salemba Empat, Jakarta. Harahap, Sofyan Syafri, 2001.

[14] Munandar. Pokok-Pokok Intermediate Accounting, Yogyakarta : Liberty, 1996.

[15] Swastha, Basu \& Handoko. Manajemen Pemasaran, Analisa dan Perilaku Konsumen. Yogyakarta: BPFE, 1997.

[16] Pride, William. M dan O. C. Ferrel. Pemasaran Teori dan Praktek Sehari-hari. Jakarta: Penerbit Binarupa Aksara, 1995.

[17] Kotler, Philip. Manajemen Pemasaran. Jakarta. Penerbit Erlangga, 1955.

[18] Dimas Prasetyo, Zahroh Z.A dan Devi Farah Azizah. Pengaruh Keputusan Investasi dan Keputusan Pendanaan Terhadap Nilai Perusahaan. (Studi pada Perusahaan Sektor Properti dan Real Estate yang Terdaftar di BEI Periode Tahun 2009-2011), 2011.

[19] Lihan Rini Puspo Wijaya, Bandi dan Anas Wibawa. Pengaruh Keputusan Investasi, Keputusan Pendanaan, dan Kebijakan Terhadap Nilai Perusahaan. Efek Indonesia, 2010.

[20] Putu Terestiani Dadri. Pengaruh Investment Opportunity Set dan Struktur Modal Terhadap Return Saham pada Perusahaan Farmasi di Bursa, 2011

[21] Hasanat, N. U.Apakah Wanita Lebih Depresif Daripada Pria? Laporan penelitian (tidak diterbitkan). Yogyakarta: Fakultas Psikologi Universitas Gadjah Mada, 1994. 
[22] Khairani Rahma dan Putri Dona Eka."Perbedaan Kematangan Emosi Pada Pria dan Wanita yang Menikah Muda", Proceeding PESAT (Psikologi, Ekonomi, Sastra, Arsitektur, \& Sipil) Vol 3, Depok: Universitas Gunadarma, pp. A1-A6, 2009.

[23] Santrock, John W. Adolescence. Perkembangan Remaja. Edisi Keenam. Jakarta: Erlangga, 2003.

[24] Ghozali, I \& Fuad. Structural Equation Modeling (Teori, Konsep dan Aplikasi dengan Program LISREL 8.54). Semarang: Badan Penerbit Universitas Diponegoro, 2005.

[25] Hair, J.F. JR.,Anderson, R.E, Tatham, R.L. \& Black, W.C. Multivariate Data Analysis. Fifth Edition. Prentice Hall, International, Inc, 1988. 